\title{
REVITALISASI NILAI-NILAI MORAL KEAGAMAAN DI ERA GLOBALISASI MELALUI PENDIDIKAN AGAMA
}

\author{
Oleh: \\ Ida Bagus Suradarma \\ STMIK STIKOM Bali \\ Jl. Raya Puputan 86 Renon Denpasar \\ suradarma@stikom-bali.ac.id
}

\begin{abstract}
Revitalization of the religious moral values is very important. It is because the incessant scourge of the culture of consumerism and hedonism stemming from malfeasance in adopting the Western culture. The globalization has shaken the sense of confidence, so that the legacy of the past of this nation is considered obsolete and must be replaced with the new ones derived from that of the modern Western civilization. Based on these symptoms, the purpose of this research is to revitalize the religious moral values which are perceived to have begun to decline. The data collection method with documentation study, the analysis technique utilized in this study was the qualitative analysis. Based on the results of the analysis and discussion, it can be concluded that the revitalization of religious moral values is through the religious education in order to be able to restore the people's self-confidence (identity). Therefore, the society does not going with the current of modern culture in this era of globalization in order to become a strong nation and noble character as has been inherited by the nation's predecessors, the anchestors.
\end{abstract}

Keywords: Revitalization, Religious Moral Values, Religious Education

\begin{abstract}
Abstrak
Revitalisasi nilai-nilai moral keagamaan menjadi sangat penting untuk dilakukan, mengingat gencarnya gerusan budaya konsumerisme dan hedonisme yang bersumber dari kelatahan dalam mengadopsi semua yang berbau Barat. Globalisasi telah menggoyahkan rasa percaya diri, sehingga warisan masa lalu bangsa ini dianggap usang dan harus diganti dengan yang baru berasal dari peradaban Barat modern. Berdasarkan gejala tersebut, maka tujuan penelitian ini adalah untuk merevitalisasi nilai-nilai moral keagamaan yang dirasa sudah mulai menurun kualitasnya. Metode pengumpulan data dengan studi dokumentasi, teknik analisis yang digunakan dalam penelitian ini adalah analisis kualitatif. Berdasarkan hasil analisis dan pembahasan dapat disimpulkan bahwa revitalisasi nilai-nilai moral keagamaan adalah melalui Pendidikan agama agar mampu mengembalikan kepercayaan diri masyarakat (jati diri), agar masyarakat tidak terbawa arus budaya modern di era globalisasi ini, agar menjadi bangsa yang kuat dan berbudi pekerti luhur, sebagaimana yang sudah diwariskan oleh para pendahulu bangsa.
\end{abstract}

Kata kunci: Revitalisasi, Nilai Moral Keagamaan, Pendidikan Agama. 


\section{PENDAHULUAN}

Pertarungan ideologi, pandangan, dan faham serta aliran madzhab yang beraneka ragam dan berkembang di masyarakat merupakan fenomena kehidupan sosial yang berlangsung saat ini. Desakan nilai-nilai budaya yang bersumber dari peradaban Barat modern yang mengalir deras sejalan dengan proses globalisasi ditengarai telah ikut mewarnai degradasi moral bangsa Indonesia (Fauzan 2011). Degradasi moral remaja merupakan suatu keprihatinan yang sangat mendalam bagi suatu bangsa. Dimana tulang punggung bangsa rapuh karena termakan oleh hancurnya moral. Sedangkan moral adalah cerminan hidup bagi penegak bangsa. Pemuda adalah harapan bangsa, di pundak merekalah masa depan bangsa dipertaruhkan. Jika pemudanya hancur, maka hancurlah bangsa tersebut (Ai Roudotul, 2012).

Moral yang seharusnya menjadi pengendali dalam bertingkah laku kian hari kian terkikis oleh kemajuan IPTEK abad 21. Menurut Widjaja (1985) dalam Windi dan Nana (2017) bahwa moral adalah ajaran baik dan buruk tentang perbuatan dan kelakuan (akhlak). Moralitas sebagai bentuk kesepakatan masyarakat mengenai apa yang layak dan apa yang tidak layak dilakukan, mempunyai sistem hukum sendiri. Hampir semua lapisan masyarakat mempunyai suatu tatanan masing-masing, bahkan komunitas terkecil masyarakat kadang mempunyai moral/etika tersendiri dengan sistemnya sendiri. Tidak jarang hukuman bagi mereka yang melanggar moralitas, lebih kejam daripada hukuman yang dijatuhkan oleh institusi formal. Hukuman terberat dari seorang yang melanggar moralitas adalah beban psikologis yang terus menghantui, pengucilan dan pembatasan dari kehidupan yang 'normal' (Sofa, 2013).

Perubahan-perubahan yang dihadapi dalam kehidupan bermasyarakat, berbangsa dan bernegara yang berlangsung sangat cepat. Pengaruh ini adalah dampak dari adanya arus Globalisasi. Globalisasi adalah suatu proses di mana antar individu, antar kelompok, dan antar negara saling berinteraksi, bergantung, terkait, dan memengaruhi satu sama lain yang melintasi batas negara. Melalui teknologi modern memungkinkan terciptanya komunikasi bebas lintas benua, lintas negara, menerobos berbagai pelosok perkampungan di pedesaan dan menyelusup di gang-gang sempit di perkotaan, melalui media audio (radio) dan audio visual (televisi, internet, dan lain-lain). Fenomena modern yang terjadi di awal milenium ketiga ini popular dengan sebutan globalisasi (Anggun, 2013).

Sebagai akibatnya, media televisi dapat dijadikan alat yang sangat ampuh di tangan sekelompok orang atau golongan untuk menanamkan atau merusak nilai-nilai moral anak bangsa. Persoalan sebenarnya terletak pada komunikasi global dalam memberikan criteria nilai-nilai moral yang baik dan buruk, antara kebenaran sejati dan yang artifisial. Di sisi lain era kontemporer identik dengan era sains dan teknologi, yang pengembangannya tidak terlepas dari studi kritis dan riset yang tidak kenal henti (Anggun, 2013). Di tengah keterbukaan inilah pentingnya penguatan kepribadian yang bermoral pada diri anak berbasis agama, karena sekarang ini moralitas yang dipilih juga akan mempengaruhi kekuatan pengaruhnya pada diri seseorang, yang dapat berakibat pada kekuatan prinsip dirinya untuk bisa memilih dan memilah serta memutuskan yang baik dan tidak baik, yang pantas dan yang tidak pantas bagi dirinya. Jangan sampai terjadi, merasa sudah membekali moralitas pada remaja, namun keliru dengan moralitas yang hampa karena ditegakkan dari nilai-nilai spiritual. Di sinilah peran penting pendidikan agama yang integral dan fungsional dalam mengantisipasi degradasi moral remaja di era global (Sofa, 2013).

Remaja sebagai generasi penerus bangsa merupakan generasi yang paling penting harus diperhatikan dan dibina dengan baik, karena merekalah yang akan meneruskan cita-cita dan perjuangan bangsa ini menjadi lebih baik dan berwibawa kedepannya. Hal yang harus dibangun bangsa ini adalah kehidupan moral dan etika generasi bangsa supaya dihargai oleh bangsa lainya dan menjadi bangsa yang berwibawa, serta tidak luntur dari nilai-nilai agama dan etika (Muhamad, 2017). Para pakar psikologi rata-rata memandang masa remaja sebagai masa yang penting yang sangat mempengaruhi perjalanan hidup seseorang. Hoffman memandang masa remaja sebagai masa pembentukan sikap-sikap terhadap segala sesuatu yang dialami individu; Conger dan 
Erikson menyebut masa remaja sebagai masa yang amat kritis yang mungkin dapat menjadi the best of time and the worst of time. Kalau seorang remaja mampu mengatasi berbagai tuntutan secara integratif maka ia akan menemukan identitasnya yang akan dibawa menjelang masa dewasanya, namun sebaliknya jika ia gagal, maka ia akan berada pada krisis identitas (identity crisis) yang berkepanjangan. Masa remaja mayoritas menghadapi ketidakstabilan emosi dalam usahanya menyesuaikan diri dengan pola prilaku baru dan harapan sosial yang baru (Nurihsan dan Agustin, 2013).

Suatu hal yang harus diwaspadai pada masa remaja awal yaitu adanya perasaan ambivalensi. Perasaan ambivalensi ini bisa sangat membahayakan jika remaja terpengaruh pergaulan orang dewasa atau remaja yang dianggapnya lebih dewasa daripadanya yang mempunyai kecenderungan nakal. Posisi puncak kelabilan remaja, kalau tidak diarahkan dan dibimbing dalam keadaan remaja seperti ini maka remaja akan terjerumus dalam kejahatan remaja (juvenile delinquency), namun sebaliknya jika mampu mendapatkan bimbingan dan diarahkan oleh orang yang tepat, maka akan bisa monorehkan prestasi puncaknya pada masa emas di remajanya (golden age adolescence) (Sofa, 2013). Melihat berbagai fenomena yang terjadi deawas ini, sangat penting untuk merevitalisasi nilai-nilai moral keagamaan yang dirasa telah terabaikan akibat gerusan budaya konsumerisme dan hedonisme yang bersumber dari kelatahan dalam mengadopsi semua yang berbau Barat. Globalisasi telah menggoyahkan rasa percaya diri generasi, sehingga muncul anggapan bahwa segala sesuatu yang datang dari warisan masa lalu bangsa ini dianggap usang dan harus diganti dengan yang baru berasal dari peradaban Barat modern.

\section{KAJIAN TEORI}

\subsection{Revitalisasi}

Revitalisasi merupakan upaya masyarakat untuk mengadakan suatu perubahan tatanan kehidupan masyarakat yang berlangsung, baik dengan menghidupkan suatu tuntunan masyarakat yang hampir punah maupun yang mengarah pada penciptaan budaya baru yang dianggap memberikan suasana yang lebih baik
(Ibrahim, 2012). Secara kebahasaan, revitalisasi berarti proses, cara atau tindakan untuk memvitalkan (menganggap penting) kembali. Revitalisai diartikan sebagai peninjauan ulang mengenai suatu hal untuk ditata, digarap, dan disesuaikan agar lebih bermanfaat dalam arti luas. Revitalisasi adalah upaya untuk memvitalkan kembali suatu kawasan atau bagian kota yang dulunya pernah vital/hidup tetapi kemudian mengalami kemunduran/ degradasi. Proses revitalisasi sebuah kawasan mencakup perbaikan aspek fisik, aspek ekonomi dan aspek social (Bambang, 2013).

Konsep revitalisasi memerlukan bukti-bukti yang didasarkan pada filosofi, kepercayaan, sosio-budaya, dan latar kesejarahan yang ditandai pada tradisi yang harmonis, teratur dengan kondisi lingkungan dan keindahan yang tidak ditentukan secara individual karena masing-masing dari dorongan mereka memperkuat dan berpengaruh satu sama lain (Bambang, 2013). Secara umum revitalisasi diharapkan mampu untuk: 1) menghidupkan kembali menurunnya kualitas suatu moral masyarakat, 2) meningkatkan kemampuan masyarakat agar memiliki nilai ekonomis dan nilai strategis, 3) mendorong penguatan nilai moral dan etika untuk mengantisipasi arus globalisasi, 5) memperkuat identitas diri bangsa Indonesia yang kaya akan agama, moral, budaya, dan etika, 6) mendukung pembentukan citra Bangsa Indonesia yang bermartabat dan berbudi luhur.

\subsection{Nilai Moral Keagamaan}

Penanaman nilai-nilai akhlak, moral, dan budi pekerti seperti tertuang dalam Undangundang Republik Indonesia Nomor 20 Tahun 2003 tentang Sistem Pendidikan Nasional harus menjadi dasar pijakan utama dalam mendesain, melaksanakan, dan mengevaluasi sistem pendidikan nasional. Pendidikan nasional berfungsi mengembangkan kemampuan dan membentuk watak serta peradaban bangsa yang bermartabat dalam rangka mencerdaskan kehidupan bangsa agar menjadi manusia yang beriman dan bertakwa kepada Tuhan Yang Maha Esa, berakhlak mulia, sehat, berilmu, cakap, kreatif, mandiri, dan menjadi warga negara yang demokratis serta bertanggung jawab.

Ditinjau dari ajaran agama Hindu, orang yang 
berkarakter selalu berpijak pada kebenaran, kebajikan, kebijaksanaan, cinta kasih, kedamaian, dan dalam memenuhi keinginan serta mendapatkan harta selalu dikendalikan oleh Dharma (Gunadha, 2012 dalam Redi, 2013). Hubungan antara akhlak dengan moral tidak dapat dipisahkan, dimana moral berarti keadaan batin yang menentukan perilaku manusia dalam menentukan sikap, tingkah laku, dan perbuatannya. Dalam agama Islam, moral dikenal dengan sebutan al- akhlaq al karimah, yaitu kesopanan yang tinggi yang merupakan pengejawantahan (manifestasi) dari keyakinan terhadap baik dan buruk, pantas dan tidak pantas yang tergambar dalam perbuatan lahir manusia (Karim, 2013).

Nilai agama dan akhlak (moral) sangat penting bagi kehidupan suatu bangsa. Dalam dunia pendidikan, pembinaan akhlak merupakan salah satu fungsi untuk memperbaiki kehidupan bangsa, selain itu perlu juga adanya pengembangan ilmu. Bangsa Indonesia meyakini bahwa kedua fungsi itu terjalin dengan eratnya. Kolaborasi antara ilmu dan akhlak menjadi mutlak dalam rangka menciptakan generasi Beragama, bermoral, beradab dan bermartabat. Ilmu dikembangkan dengan dasar akhlak yang kuat agar membawa kemanfaatan dan kebaikan (Asti, 2017). Terkait dengan pengembangan moralitasnya, harus dimulai sejak anak usia dini, agar terbentuk karakter (formation of character), terbentuknya kepribadian (shaping of personality), dan perkembangan sosial (social development) (Hidayat, 2015). Pembentukan karakter pada diri seorang anak didapatkan pada lingkungan sekitarnya yaitu lingkungan keluarga, masyarakat dan lingkungan sekolah. Lingkunga keluarga merupakan lingkungan terdekat yang dapat memberikan pengaruh pada karakter seorang anak. Selain keluarga, lingkungan terdekat seperti tetangga atau teman sebaya juga akan memberikan pengaruh yang cukup signifikan dalam pengembangan moral seorang anak (Asti, 2017).

Menurut John Dewey, tahapan perkembangan moral seseorang akan melewati tiga fase (Hidayat, 2015) yaitu: (1) Fase premoral atau preconventional: pada level ini sikap dan perilaku manusia banyak dilandasi oleh impuls biologis dan sosial, (2) Tingkat konvensional; perkembangan moral manusia pada tahapan ini banyak didasari oleh sikap kritis kelompoknya,
(3) Autonomous: pada tahapan ini perkembangan moral manusia banyak dilandasi pola pikirnya sendiri. Pada tahapan ini seorang anak telah memiliki kemampuan sendiri dalam menentukan segala keputusan sikap dan perilaku moralitasnya.

\section{METODE PENELITIAN}

Jenis data yang digunakan dalam penelitian ini adalah data kualitatif yakni data yang berbentuk kata, kalimat, yang hanya merupakan keterangan-keterangan atau informasi. Sumber data dalam penelitian ini adalah data sekunder. Data sekunder adalah data yang sudah diolah pihak lain dan dapat berasal dari berbagai buku bacaan, jurnal-jurnal dan laporan hasil penelitian sejenis yang dapat diacu dan dapat dijadikan referensi.

Teknik pengumpulan data dalam peneliti ini adalah melalui studi dokumentasi yakni cara pengumpulan data dengan mempelajari bukubuku bacaan, dokumen-dokumen, jurnal hasil penelitian. Teknik analisis data yang digunakan adalah analisis data kualitatif yakni sebagai prosedur penelitian yang menghasilkan data deskriptif. Deskriptif dapat diartikan sebagai prosedur pemecahan masalah yang diselidiki dengan menggambarkan/melukiskan keadaan subjek/objek penelitian (seseorang, lembaga, masyarakat dan lain-lain) pada saat sekarang berdasarkan fakta-fakta yang tampak atau sebagaimana adanya (Bodgan dan Taylor dalam Moleong, 2017).

Data kualitatif hadir dalam wujud catatan harian yang diperoleh dari hasil pengamatan, dari kutipan berbagai dokumen dengan tahapan sebagai berikut: 1) Reduksi data adalah menulis atau mengetik data dan menguraikan data serta melaporkan secara terinci (ditambah atau membuang data yang tidak perlu atau dianggap kurang penting); 2) Penyajian data dilakukan dengan mengambil dari berbagai teks naratif, grafik, jaringan, tabel, dan bagan, yang selanjutnya dilakukan penarikan kesimpulan dan pengambilan tindakan. 3) Penarikan kesimpulan mencakup verifikasi dengan cara: memikir ulang selama penulisan, tinjauan ulang pada catatan-catatan lapangan, peninjauan kembali dan tukar pikiran dan diskusi antar teman sejawat (Kaelan, 2012). Analisis data kualitatif dimaksudkan untuk memberi 
gambaran, menerangkan, membandingkan, dan menjelaskan secara deskriptif tentang nilai-nilai moral keagamaan.

\section{PEMBAHASAN}

\subsection{Pendidikan Agama}

Pendidikan agama di negara kita sebenarnya sudah ada jauh sebelum kemerdekaan. Namun karena politik pendidikan pemerintah penjajah (Belanda), maka di sekolah-sekolah negeri tidak diberikan pendidikan agama. Politik pendidikan yang demikian dikatakan 'neutraal', artinya pihak pemerintah tidak mencampuri masalah pendidikan agama, sebab agama dianggap menjadi tanggung jawab keluarga (Zakiyah, 1996). Pendidikan agama merupakan usaha berupa bimbingan dan asuhan terhadap anak didik supaya kelak setelah selesai pendidikannya dapat memahami dan mengamalkan ajaranajaran agama serta menjadikannya sebagai way of life (Abdul 2000).

Sasaran pendidikan agama adalah kepribadian. Pendidikan agama berusaha mengarahkan kepada pembentukan kepribadian anak-anak sesuai dengan ajaran agama. Pendidikan agama dilakukan dengan usahausaha sistematis dan pragmatis dalam membantu anak-anak agar hidup sesuai dengan ajaran agama (Mahfudh, 1987). Oleh karena itu, pendidikan agama berkisar pada dua dimensi kehidupan manusia, yaitu penanaman rasa taqwa kepada Tuhan Yang Maha Kuasa dan pengembangan rasa kemanusiaan kepada sesama. Jiwa taqwa akan berkembang dengan menghayati keagungan dan kebesaran Tuhan melalui rasa perhatian kepada alam semesta beserta segala isinya, dan lingkungan sekitarnya. Di samping itu pendidikan agama bagi generasi penerus bangsa dilihat dari dimensi kemanusiaan yakni seberapa jauh tertanam nilai-nilai keagamaan dalam jiwa anak, serta seberapa jauh nilai-nilai itu berwujud nyata dalam tingkah laku dan budi pekerti (Nurcholish, 2000).

Begitu panjangnya sejarah eksistensi pendidikan agama di negeri kita yang pada akhirnya mendapat kedudukan yang sangat diperhitungkan. Berdasarkan regulasi yang berlaku (Undang-Undang No. 20 Tahun 2003), pendidikan agama adalah hak peserta didik. Diperjelas pada Undang- Undang tersebut Bab V pasal 12 ayat (1), yang berbunyi: setiap peserta didik pada satuan pendidikan berhak: (a) mendapat pendidikan agama sesuai dengan agama yang dianutnya dan diajarkan oleh pendidik yang seagama. Dalam penjelasan pasal 12 (1) a, disebutkan bahwa pendidik dan/atau guru agama yang seagama dengan peserta didik difasilitasi dan/atau disediakan oleh pemerintah atau pemerintah daerah sesuai dengan kebutuhan satuan pendidikan sebagaimana diatur dalam pasal 41 ayat (3). Dalam UndangUndang Pendidikan sebelumnya, UndangUndang No.2 Tahun 1989 disebutkan bahwa salah satu dari tiga mata pelajaran pendidikan (pendidikan Pancasila, pendidikan agama, dan pendidikan kewarganegaraan) (UU Nomor 2 Tahun 1989 pasal 39 ayat (2)). Agama mengatur hubungan manusia dengan Tuhan Yang Maha Esa, hubungan manusia dengan manusia, hubungan manusia dengan alam, dan hubungan manusia dengan dirinya yang dapat menjamin keselarasan, keseimbangan, dan keserasian dalam hidup manusia, baik sebagai pribadi maupun sebagai anggota masyarakat dalam mencapai kemajuan lahiriyah dan rohaniyah (Zakiyah Daradjat, 1996).

Agama sebagai dasar tata nilai dan penentu dalam perkembangan dan pembinaan rasa kemanusiaan yang adil dan beradab, maka pemahaman dan pengalamannya dengan tepat dan benar diperlukan untuk menciptakan kesatuan bangsa. Materi pendidikan agama bagi masing-masing pemeluknya berasal dari sumber-sumber agamanya masing-masing. Pelaksanaan pendidikan agama dilakukan oleh pengajar yang meyakini, mengamalkan, dan menguasai materi agama tersebut. Pendidikan agama sangatlah urgent, maka Pendidikan agama dikelompokkan kepada pendidikan yang wajib diberikan kepada seluruh peserta didik sesuai dengan agama yang dianutnya. Pendidikan agama itu tentunya dilaksanakan untuk mencapai terwujudnya pendidikan nasional pada aspek beriman dan bertakwa kepada Tuhan Yang Maha Esa serta berakhlak mulia (Bab II, pasal 3 UU No. 20 Tahun 2003). Lebih dipertegas lagi kedudukan pendidikan agama pada Bab V, pasal 12 (1) UU No. 20 Tahun 2003 mengenai hak peserta didik. Setiap peserta didik pada setiap satuan pendidikan berhak mendapat pendidikan agama yang sesuai dengan agama yang dianutnya dan diajarkan 
oleh pendidik yang seagama.

Mengingat pendidikan agama merupakan bagian pendidikan yang sangat penting yang berkenaan dengan aspek-aspek sikap dan nilai, antara lain akhlak dan keagamaan, maka pendidikan agama juga menjadi tanggung jawab keluarga, masyarakat dan pemerintah. Keluarga sebagai instansi pendidikan yang dasar dan menjadi tempat untuk menanamkan pendidikan agama secara dini. Begitu juga masyarakat dan pemerintah melalui instansi atau lembaga bentukannya juga sangat berperan penting untuk menumbuhkembangkan nilai agama pada pribadi anak. Ketiga instansi ini (keluarga, masyarakat, dan pemerintah) harus saling mendukung dan bersinergi untuk tujuan bersama dalam penanaman nilai agama. Ketiga lembaga pendidikan tersebut merupakan bagian yang integrated dalam menanamkan moralitas anak (Aris, 2001).

\subsection{Pendidikan Moral}

Menurut Mulyasa (2011), bahwa pendidikan merupakan sesuatuyang dapat mengembangkan potensi masyarakat, mampu menumbuhkan kemauan, serta membangkitkan nafsu generasi bangsa untuk menggali berbagai potensi, dan mengembangkannya secara optimal bagi kepentingan pembangunan masyarakat secara utuh dan menyeluruh. Pendidikan sejati merupakan proses pembentukan moral masyarakat beradab, masyarakat yang tampil dengan wajah kemanusiaan dan pemanusiaan yang normal. Kata lainnya, pendidikan adalah 'moralisasi masyarakat' terutama peserta didik (Sudarwan, 2006). Pengertian 'moral' memiliki pengertian yang sama dengan akhlak (khulq), character, dispotsition, budi pekerti, dan etika (Muhaimin et al., 2007). Moralitas, moralisasi, tindakan moral, dan demoralisasi merupakan realitas hidup dan ada di sekitar kita (Sudarwan, 2006).

Berdasarkan tujuan pendidikan nasional yang tercantum dalam GBHN dan tujuan kelembagaan sekolah serta tujuan pendidikan moral yang diberikan pada tingkat sekolah dan perguruan tinggi, maka pendidikan moral di Indonesia bisa dirumuskan untuk sementara sebagai berikut: "Pendidikan moral adalah suatu program pendidikan (sekolah dan luar sekolah) yang mengorganisasikan dan menyederhanakan sumber-sumber moral dan disajikan dengan memperhatikan pertimbangan psikologis untuk tujuan pendidikan" (Nurul, 2008 dalam Mochamad, 2016). Dreeben dalam Nurul Zuriah (2008), menyatakan bahwa tujuan pendidikan moral akan mengarahkan seseorang menjadi bermoral, yang penting adalah bagaimana agar seseorang dapat menyesuaikan diri dengan tujuan hidup bermasyarakat.

Terkait dengan pendidikan moral yang berkembang di Indonesia ada beberapa hal yang dapat dijadikan pertimbangan yaitu: Pertama, dengan mempelajari kawasan nilai-nilai sentral seperti tercantum dalam tujuan pendidikan nasional yang dirumuskan dalam GBHN dan Undang-Undang Sistem Pendidikan Nasional, maka pendidikan moral di Indonesia bertujuan untuk menanamkan seperangkat nilai-nilai yang menjadi ciri manusia Indonesia seutuhnya yang menyelaraskan nilai-nilai agama dan kebudayaan. (Koentjaraningrat, 2004). Kedua, pendidikan moral adalah suatu program (sekolah dan luar sekolah) yang mengorganisasikan dan menyederhanakan sumber moral serta disajikan dengan memerhatikan pertimbangan psikologis untuk tujuan pendidikan. Pendidikan diselenggarakan sebagai suatu proses pembudayaan dan pemberdayaan peserta didik yang berlangsung sepanjang hayat. Ketiga, erat hubungannya dengan upaya meningkatkan keimanan dan ketakwaan kepada Tuhan. Keempat, Pendidikan diselenggarakan dengan memberi keteladanan, membangun kemauan, dan mengembangkan kreativitas peserta didik dalam proses pembelajaran. Kelima, pendidikan moral, hendaknya memperkaya pendidikan moral agar terjadi pula penalaran moral (moral reasoning) dan perkembangan moral kognitif (cognitive moral development). Keenam, pendekatan metode penyampaian berorientasi pada field psychology, pendekatan pemecahan masalah, dan metode inkuiri. Ketujuh, upaya mencapai keberhasilan dalam pendidikan moral merupakan tanggung jawab bersama. Oleh karena itu, pengertian hidden curriculum perlu dikembangkan agar seluruh program di sekolah dan masyarakat memberikan sumbangan dalam meningkatkan keberhasilan pendidikan moral. Peran serta masyarakat dalam pendidikan meliputi peran serta perseorangan, kelompok, keluarga, organsasi profesi, pengusaha, dan organisasi kemasyarakatan dalam 
penyelenggaraan dan pengendalian mutu pelayanan pendidikan (Nurul, 2008 dalam Fauzan (2011).

\subsection{Revitalisasi Nilai-nilai Moral}

Persoalan rendahnya moral keagamaan merupakan sebuah dilema yang dapat menghambat kemajuan bangsa ke depan. Di samping itu gerusan zaman yang sedikit banyak berpengaruh cukup besar pada degradasi nilainilai moral keagamaan. Menurut Greg Fealy peran agama dalam era globalisasi telah berubah begitu cepat. Teknologi baru dan arus informasi yang begitu deras, ditopang oleh arus urbanisasi yang tak terkendali, telah mendorong munculnya bermacam-macam ekspresi keagamaan yang mengundang selera berbagai pihak untuk ikut "memperdagangkan"-nya. Namun di sisi lain, komodifikasi agama juga dikhawatirkan akan mengarah pada pendangkalan makna spiritualitas itu sendiri, sebab kecenderungan seperti itu hanya bersentuhan dengan aspek penampilan luar atau lahiriah. Pendangkalan itu lebih jauh bisa berdampak pada hilangnya aspek intelektualitas dalam memahami makna ajaran agama yang sebenarnya, serta rapuhnya apresiasi nilai-nilai spiritualitas yang dibangun oleh keimanan. Kenyataan ini yang harus menjadi pertimbangan di dalam mengembangkan wacana moralitas berbasis nilai- nilai keagamaan. Ada aspek lain yang juga layak dipertimbangkan dalam merekonstruksi wacana moral keagamaan yang perlu direvitalisasi (Fauzan, 2011).

Adapun upaya revitalisasi untuk menumbuhkan nilai-nilai moral keagamaan pada generasi bangsa adalah sebagai berikut. Pertama, melalui pendidikan agam yakni dengan memberi teladan bagi generasi penerus bangsa. Membiasakan peserta didik dan lingkungan pendidikan untuk menghidupkan dan menegakkan nilai-nilai yang benar. Segenap civitas harus masing-masing bisa menjadi "teladan yang hidup" bagi para peserta didik. Harus siap untuk bersikap terbuka dan mendiskusikan nilai-nilai moralitas yang baik tersebut dengan para peserta didik, sehingga terjadi proses internalisasi intelektual bagi peserta didik. Kedua, dengan memantapkan kembali pelaksanaan pendidikan agama, karena nilai-nilai dan ajaran agama pada akhirnya ditujukan untuk membentuk moral yang baik.
Ketiga, pendidikan agama yang dapat menghasilkan perbaikan moral harus dirubah dari model pengajaran agama kepada pendidikan agama. Pengajaran agama maksudnya hanya transfer of religion knowledge (mengalihkan pengetahuan agama) atau mengisi anak dengan pengetahuan tentang agama, sedangkan pendidikan agama bisa berarti membina dan mewujudkan perilaku manusia yang sesuai dengan tuntutan agama (Ki Butarsono dalam Yulianingsih, 2002).

Pendidikan anak bisa dilakukan dengan membiasakan anak berbuat baik dan sopan santun tentang berbagai hal mulai sejak kecil sampai dewasa. Selanjutnya ketika berbicara dibiasakan berbicara yang baik, dalam pergaulan dibiasakan pula harus memiliki sikap rendah hati, dan bersahabat dengan orang lain. Dibiasakan juga bersikap jujur, adil, konsekuen, ikhlas, pemaaf, sabar, berbaik sangka, dan sebagainya dalam berbagai aspek kehidupan. Keempat, pendidikan moral dapat dilakukan dengan pendekatan integrated, yaitu dengan melibatkan seluruh disiplin ilmu pengetahuan. Pendidikan moral bukan hanya terdapat dalam pendidikan agama saja, melainkan juga terdapat pada pelajaran bahasa, logika, matematika, fisika, biologi, sejarah, dan sebagainya.

Pelajaran bahasa misalnya melatih dan mendidik manusia agar berbicara yang sistematis. Pelajaran matematika mendidik manusia berpikir yang sistematis dan logis, objektif, jujur, ulet, dan tekun. Pelajaran fisika mendidik manusia agar mensyukuri naikmatnikmat Tuhan yang terdapat pada ciptaan-Nya. Pelajaran Biologi mendidik manusia agar bekerja teratur. Dan, pelajaran sejarah mendidik manusia agar selalu berpihak pada kebenaran. Kelima, pendidikan moral harus melibatkan seluruh guru, karena bukan hanya menjadi tanggung jawab guru agama saja, melainkan menjadi tanggung jawab seluruh guru. Keenam, pendidikan moral harus didukung oleh kemauan, kerja sama yang kompak dan usaha yang serius dari keluarga/rumah tangga, sekolah, dan masyarakat. Orang tua di rumah harus meningkatkan perhatiannya terhadap anak-anaknya dengan meluangkan waktu untuk memberikan bimbingan, teladan, dan pembiasaan yang baik. orang tua juga harus berupaya menciptakan rumah tangga yang harmonis, tenang, dan tentram sehingga si anak 
merasa tenang jiwanya dan dengan mudah dapat diarahkan kepada hal-hal yang positif. Sekolah juga harus berupaya menciptakan lingkungan yang bernuansa religius, menegakkan disiplin dalam kebersihan, ketertiban, kejujuran, tolong-menolong, sehingga nilai-nilai agama menjadi kebiasaan, tradisi, atau budaya seluruh siswa. Sementara itu masyarakatjuga harus berupaya menciptakan lingkungan yang kondusif bagi pembentukan akhlak, seperti melakukan kegiatan gotong royong, kerja bakti, memelihara ketertiban dan kebersihan, menjauhi hal-hal yang dapat merusak moral.

Masyarakat harus membantu menyiapkan tempat bagi kepentingan pengembangan bakat, hobi, dan keterampilan para remaja, seperti lapangan olah raga, balai-balai latihan, dan sebagainya. Ketujuh, pendidikan moral harus menggunakan seluruh kesempatan, berbagai sarana termasuk teknologi modern. Kesempatan berekreasi, pameran, kunjungan, berkemah, dan sebagainya harus digunakan sebagai peluang untuk membina moral. Demikian pula berbagai sarana seperti masjid, mushola, lembagalembaga pendidikan, surat kabar, majalah, radio, televisi, internet, dan sebagainya dapat digunakan untuk membina moral. Kedelapan, penanaman moral dapat dilakukan dengan membangun dan meningkatkan kekuatan hati nurani moral (moral consequence) dengan cara meningkatkan rasa keagamaan yang mendalam (spiritualitas) terlebih dahulu. Pendidikan diarahkan untuk Touching bukan pada Teaching semata. Spiritualitas di sini adalah inti dari hati nurani moral (moral consequence). Hati nurani moral ini merupakan kekuatan ruhaniyah dan keimanan yang memberi semangat kepada seseorang untuk berbuat terpuji (good character) dan menghalanginya dari berbuat jahat (bad character) (Mochamad, 2016).

\section{PENUTUP}

Berdasarkan hasil analisis dan pembahasan dapat disimpulkan bahwa sangat penting untuk merevitalisasi nilai-nilai moral keagamaan di Era Globalisasi melalui Pendidikan agama dengan memberi teladan bagi generasi penerus, memantapkan kembali pelaksanaan Pendidikan agama, model pengajaran harus dirubah dari transfer pengetahuan agama menjadi Pendidikan agama, Pendidikan agama harus melibatkan seluruh disiplin ilmu, harus melibatkan seluruh guru, harus didukung oleh semua pihak yakni keluarga, sekolah dan masyarakat, agargerusan budaya konsumerisme dan hedonisme yang bersumber dari kelatahan dalam mengadopsi semua yang berbau Barat akan dapat dikurangi bahkan ditiadakan.

\section{DAFTAR PUSTAKA}

Abdul, R. S. 2000. Pendidikan Agama dan Keagamaan. Visi. Misi. dan Aksi. Jakarta: Gemawindu Pancaperkasa.

Ai, Roudotul. 2012. Degradasi Moral Remaja. http://aiirm59.blogspot.co.id/2012/ 06/degradasimoral-remaja.html.

Anggun, G. 2013. Pentingnya Menumbuhkan Pendidikan Moral Di Era Globalisasi, https://goenable. wordpress.com/pentingnya-menumbuhkan-pendidikan-moral-di-era-globalisasi.

Aris, M. 2001. Tata Krama di Rumah. Sekolah. dan Masyarakat. Jakarta: SIC

Asti, I. 2017. Strategi Pengembangan Moral dan Nilai Agama Untuk Anak Usia Dini, SMP Sunan Averouss Al-Athfal Yogyakarta: Jurnal Pendidikan Anak. Vol. 3 (1), 2017, ISSN Online: 2477-4189.

Bambang, S. 2013. Revitalisasi Nilai-Nilai Pancasila Melalui Pembelajaran Pkn Berbasis Kearifan Lokal Untuk Penguatan Karakter dan Jati Diri Bangsa, Varia Pendidikan,.Vol. 25. No. 2. Desember 2013.

Fauzan, S. 2011. Revitalisasi Nilai-Nilai Moral Keagamaan dalam Merespon Realitas Zaman. ISLAMICA, Vol. 6, No. 1, September 2011.

Hidayat, O. S. 2015. Metode Pengembangan Moral dan Nilai-Nilai Agama, Tangerang Selatan: Universitas Terbuka. 
Ibrahim, L. 2012. Makalah Pengertian Revitalisasi Agama, http://www.Aneka makalah. com/2012/03/revitalisasi-agama.html.

Kaelan. 2012. Metode Penelitian Kualitatif Interdisipliner Bidang Sosial, Budaya, Filsafat, Seni, Agama, dan Humaniora, Yogyakarta: Paradigma.

Karim, A. 2013. Islam Nusantara, Yogyakarta: Gama Media.

Kementrian Pendidikan Nasional, 2010, Pengembangan Pendidikan Budaya dan Karakter Bangsa, Bahan Pelatihan Penguasaan Metodelogi Pembelajaran Berdasarkan Nilai-nilai Budaya untuk Membentuk Daya Saing dan Karakter Bangsa, Kementrian Pendidikan Nasional, Jakarta.

Koentjaraningrat. 2004. Kebudayaan Mentalitas dan Pembangunan. Jakarta: Gramedia.

Mahfudh, S. 1987. Metodologi Pendidikan Agama. Surabaya: Bina Ilmu.

Moleong. 2017. Metode Penelitian Kualitatif, Edisi Revisi, Bandung: PT Remaja Rosdakarya.

Mochamad, I. 2016. Dekadensi Moral di Kalangan Pelajar (Revitalisasi Strategi PAI dalam Menumbuhkan Moralitas Generasi Bangsa), Fakultas Tarbiyah dan Ilmu Keguruan IAIN Pekalongan. Edukasia Islamika: 1 (1) Desember 2016/14381.

Muhamad, K. 2017. Membangun Generasi Bangsa melalui Pendidikan Moral dan Etik, https://www. kompasiana.com/www.kernianingsih.com/ membangun-generasi-bangsa-melaluipendidikan-moral-dan-etika.

Mulyasa, E. 2011. Menjadi Guru Profesional. Bandung: Remaja Rosdakarya.

Nurihsan dan Agustin, 2013, Dinamika Perkembangan Anak http:// hukum. Unmuh jember.ac.id/ in-dex.php/13-berita/11-kenakalan-remaja. diakses 17/10/2013.

Nurcholish, M. 2000. Masyarakat Religius Membumikan Nilai-Nilai Islam dalam Kehidupan Masyarakat. Jakarta: Paramadina.

Redi, A. I W. 2013. Revitalisasi Pendidikan Karakter untuk Membangun Bangsa yang Berwatak Terpuj., Denpasar: Widya Dharma UHNI Press.

Sudarwan, D. 2006. Agenda Pembaruan Sistem Pendidikan. Yogyakarta: Pustaka Pelajar

Sofa, M. 2013. Antisipasi Degradasi Moral di Era Global, Jurnal Pendidikan Islam, 7 (2) Oktober 2013.

Undang-Undang Republik Indonesia Nomor 2 Tahun 1989 Tentang Sistem Pendidikan Nasional Bab I Ketentuan Umum Pasal1.

Undang Undang Nomor 20 tahun 2003 tentang Sistem Pendidikan nasional.

Windi, S. J. R. dan Nana, S. 2017. Pendidikan Karakter Sebagai Upaya Mengatasi Degradasi Moral. Prosiding Seminar Nasional Inovasi Pendidikan Inovasi Pembelajaran Berbasis Karakter dalam Menghadapi Masyarakat Ekonomi ASEAN.http://jurnal.fkip.uns.ac.id/index. php/snip/article/viewFile/diakses, 25 Desember 2017.

Zakiah, D. 1979. Peranan Agama dalam Kesehatan Mental. Jakarta: Gunung Agung. 